\title{
CLIMATE CHANGE EFFECTS ON NEOTROPICAL MANAKIN DIVERSITY BASED ON ECOLOGICAL NICHE MODELING
}

\author{
Marina Anciães ${ }^{1}$ And A. Townsend Peterson \\ Natural History Museum and Biodiversity Research Center, 1345 Jayhawk Blvd., University of Kansas, \\ Lawrence, KS 66045-7561
}

\begin{abstract}
Assessing the nature and magnitude of potential effects of climate change on populations is important to anticipating effects on species diversity for conservation planning. We used ecological niche modeling to predict present and future distributions of 49 species of manakins (Pipridae) and allies. Predictions for present-day distributions were highly coincident with independent test data, suggesting good predictive ability. Assuming no dispersal, projections of potential distributions under four scenarios of climate change predicted that $20 \%$ of manakin species would likely go extinct from their current ranges, and that distributions would in general be reduced and fragmented, regardless of the area of present-day potential distribution or rarity. Predicted changes in potential distributions, spatial configuration of suitable habitats, and geographic position of species ranges were more dramatic for species inhabiting flatlands than for montane species. These results are an example of how ecological niche modeling techniques can anticipate the nature and magnitude of changes in biodiversity in response to climate change.
\end{abstract}

Key words: climate change, conservation, ecological niche, geographic distribution, manakin.

Efeitos de Mudanças Climáticas na Diversidade de Tangarás Neotropicais Estimados Através da Modelagem de Nicho Ecológico

\begin{abstract}
Resumo. Conhecer a natureza e magnitude dos efeitos potenciais das mudanças climáticas em populações é importante em planos de conservação por antecipar os efeitos sobre a diversidade de espécies de uma região. Modelamos o nicho ecológico de 49 espécies de tangarás (Pipridae), e espécies aparentadas, para prever suas distribuições no presente e futuro. Estimativas para o presente foram altamente coincidentes com testes independentes, indicando boa previsibilidade dos modelos. As projeções de distribuições potenciais em quatro cenários de mudanças climáticas indicam que, na ausência de dispersão, $20 \%$ das espécies de tangarás irão se extinguir de suas localidades de ocorrência atuais, e que suas distribuições se tornarão reduzidas e fragmentadas, independentemente da área de distribuição potencial e raridade no presente. Mudanças previstas na distribuição potencial, disposição espacial de habitats propícios, e posição geográfica da distribuição de espécies foram maiores para espécies habitantes de baixadas que de regiões montanhosas. Estes resultados exemplificam o uso de modelagem de nicho ecológico para antecipar a natureza e magnitude de alterações na biodiversidade decorrentes de mudanças climáticas.
\end{abstract}

\section{INTRODUCTION}

Globally, climates are undergoing dramatic changes (Karl et al. 1996, Magnuson 2001), with demonstrable effects on the distribution of biodiversity, including both colonization of new areas and local extinctions (Brown et al. 1997, Parmesan et al. 1999, Xu and Yan 2001, Walther et al. 2002). Predictions of substantial further warming and reorganization of patterns

Manuscript received 17 November 2005; accepted 6 June 2006.

${ }^{1}$ Present address: Curadoria de Aves, Instituto Nacional de Pesquisas da Amazônia, INPA. Av. André Araújo 2936 C.P. 478 Aleixo, Manaus, AM 69083 Brazil. E-mail: marina.anciaes@gmail.com of precipitation for coming decades in Neotropical regions has generated concern about consequences for biodiversity across the region (Houghton et al. 2001), where numerous biodiversity hotspots are located (Myers et al. 2000). Thus, as future climate changes will likely affect the conservation status of many species (Peters and Darling 1985, Dobson et al. 1989, Peters and Myers 1991-1992, Chapin et al. 2000, Thomas et al. 2004), studies that anticipate the pattern and magnitude of effects of climate change on distributions of Neotropical species are urgently needed.

The geographic distributions of species are defined by autecological needs and tolerances, biotic interactions, and historical effects (So- 
berón and Peterson 2005). As such, climate change may affect the spatial manifestation of ecological niches (i.e., the set of environmental conditions within which a species is able to maintain populations without immigration; Grinnell 1917, 1924). When faced with changing ecological conditions, species may track appropriate conditions or adapt to the new conditions; failing both, populations will be extirpated (Holt 1990, Brown and Lomolino 1998). As both theoretical expectations and empirical studies suggest that ecological niches remain relatively constant over long time scales (Huntley et al. 1989, Kawecki and Stearns 1993, Holt 1996, Holt and Golmukiewicz 1996, Peterson et al. 1999, Rice et al. 2003, Martínez-Meyer et al. 2004), these ecological characteristics likely present long-term stable constraints on the geographic potential of species (Peterson 2003). As such, we make the provisional assumption in this analysis that evolution in ecological characteristics will be nil, and focus on anticipating spatial shifts in the position of appropriate conditions for species.

Ecological niche models can be based on present-day distributions with respect to environmental conditions (Soberón and Peterson 2005). Once models are built and validated in present-day conditions, their rule sets can be projected onto scenarios of change for anticipating potential distributional shifts and consequent changes in diversity (Pounds et al. 1999, Peterson et al. 2001, 2004, Root et al. 2003, Roura-Pascual et al. 2005). Although many studies modeling effects of climate change on potential species distributions have shown idiosyncratic and individualistic aspects of the likely responses of different species (Perry et al. 1990, Johnston and Schmitz 1997, Kadmon and Heller 1998, Price 2000, Peterson et al. 2001), some generalities are now emerging. For example, Peterson et al. $(2001,2002)$ and Peterson (2003) showed that species in flatlands regions experienced higher predicted distributional shifts and loss in habitable area than species in montane areas. Studies examining sufficient numbers of species to permit testing these predictions, however, are quite scarce.

The manakins (Aves: Pipridae) are a diverse clade of small frugivorous birds distributed across the Neotropics. The family includes about 45 species and is broadly distributed in Neotropical forests, inhabiting lowland rain forests and other tropical forests. Additionally, manakins are easily collected, and so are wellrepresented in collections. Ecological niches are generally conserved among sister manakin species, suggesting ecological conservativism across lineages (MA and ATP, unpubl. data). The Neotropical manakins are therefore an ideal group for examining the consequences of predicted future climate changes on the distribution of Neotropical biodiversity. Here, we model ecological niches and predict future potential geography of Neotropical manakins in the face of changing climates over coming decades. We evaluate likely effects of regional topography on changes in predicted distributional area, geographic position of distributions, and fragmentation of species' ranges.

\section{METHODS}

Our approach to modeling future geographic distributions of manakin species consisted of two steps: (1) modeling ecological niches based on known occurrences and datasets summarizing present-day environmental features (climate and topography), and (2) projecting models onto environmental datasets summarizing climates predicted for future time periods (here, mid- $21^{\text {st }}$ century). The general methodology for modeling ecological niches and projecting effects of climate change on distributions is described in detail in Peterson et al. (2001).

\section{INPUT DATA}

Creation of an ecological niche model for projection across scenarios of change requires information on the occurrence of species of interest in the present day, digital raster GIS coverages summarizing climates for both time periods, and digital raster GIS coverages summarizing constant features of the landscape (e.g., topographic features, soil type). Occurrence information, in the form of unique geographic localities at which specimens of a particular species have been collected, was accumulated from data associated with natural history museum specimens for all manakin species and 10 species in closely related families (genera Neopelma, Neopipo, Piprites, and Tyranneutes). Specimen records were supplemented with data from the literature and field observations; complete lists of sources are available on request from the senior author. Sample sizes for eight species (five manakins and three from other 
families) were insufficient for generating models; these species were omitted from analysis.

We used seven electronic map layers summarizing aspects of topography (slope, aspect, and topographic index, from the U.S. Geological Survey's Hydro $1 \mathrm{k}$ elevation derivation database $<$ http://edcdaac.usgs.gov/gtopo30/hydro/ $>$ ) and climate (annual mean precipitation, annual mean maximum monthly temperature, annual mean minimum monthly temperature, and mean annual temperature; Intergovernmental Panel on Climate Change <http:// www.ipcc.ch/ $>$ ). All environmental data sets were generalized to $0.1^{\circ} \times 0.1^{\circ}$ resolution (about $10 \times 10 \mathrm{~km}$ ) for an area including all of tropical America $\left(34^{\circ} \mathrm{N}\right.$ to $\left.40^{\circ} \mathrm{S}\right)$. For refinement of modeled ecological niches, and because the aim of this study was to predict future distributions, we subdivided the study area into three subregions, based on the known distributions of most manakin species, within which models were developed (Amazon Basin, eastern South America, and northwestern Neotropics). Projections were made from these regional models to the whole study area.

\section{SCENARIOS OF CLIMATE CHANGE}

Ecological niches modeled for each species based on present-day occurrences and conditions were projected onto future climate data sets derived from two general circulation models: CGCM2, developed at the Canadian Centre for Climate Modelling and Analysis (Flato et al. 1999), and HadCM3, developed at the Hadley Centre for Climate Prediction and Research (Pope et al. 2000). For each circulation model, we averaged the results from two emissions scenarios, one conservative and one more severe set of assumptions for climates over the next 50 years: B2 assumes a $0.5 \%$ year ${ }^{-1} \mathrm{CO}_{2}$ increase and incorporates sulphate aerosol forcing, and A2 assumes a $1 \%$ year $^{-1}$ $\mathrm{CO}_{2}$ increase and does not take into account effects of sulphate aerosols (Nakicenovic and Swart 2000). Results are based on a 30 -year average around 2055 (2040-2069), thus they do not consider potential effects of increased climate variability (El Niño events in particular) on species distributions.

As global circulation model data are provided at coarse spatial resolutions (Hadley: $2.5^{\circ}$ $\times 3.75^{\circ}$; Canadian: $3.75^{\circ} \times 3.75^{\circ}$ ), we scaled all coverages down to $0.5^{\circ} \times 0.5^{\circ}$ resolution by interpolation of expected changes in each climatic layer under each scenario. Although the scenarios are the same for both circulation models, implementing simulations under contrasting assumptions regarding emissions of greenhouse gases may give different predictions among the models and scenarios (Peterson et al. 2004). Because the goal of this study was an overall exploration of likely climate effects on manakin diversity, we present average estimates based on predictions from both models and both scenarios.

\section{ECOLOGICAL NICHE MODELING}

The ecological niche of a species can be defined as the conjunction of ecological conditions within which it is able to maintain populations without immigration (Grinnell 1917, Holt and Gaines 1992); as such, it is defined in multidimensional ecological and environmental space (MacArthur 1972). Several approaches have been used to approximate ecological niches (Nix 1986, Austin et al. 1990, Carpenter et al. 1993); that which has seen broadest application to questions of ecological niche evolution is the Genetic Algorithm for Rule-set Prediction (GARP), which includes several inferential approaches in an iterative optimization approach (Stockwell and Noble 1992, Stockwell 1999, Stockwell and Peters 1999).

All modeling in this study was carried out with a desktop implementation of GARP ( $<$ http://www.lifemapper.org/desktopgarp/>). Available occurrence points are divided evenly into "training" and "extrinsic test" data sets; the former is again divided evenly into true "training data" (for model rule development) and "intrinsic test data" (for model rule evaluation and refinement). When sample sizes were $<20$ unique localities, models were developed with intrinsic testing only. GARP is designed to use only presence data; absence information is included in the modeling via sampling of pseudoabsence points from the set of pixels where the species has not been detected. GARP works in an iterative process of rule selection, evaluation, testing, and incorporation or rejection. First, a method is chosen from a set of possibilities (e.g., logistic regression, bioclimatic rules) and is applied to the training data to develop a rule; rules may evolve by a number of means (e.g., truncation, point changes, crossing-over among rules) to 
maximize predictive ability. Predictive accuracy of each rule (for use in model refinement) is then evaluated based on 1250 points resampled from the intrinsic test data set and 1250 points sampled randomly from the study region as a whole. The change in predictive accuracy from one iteration to the next is used to evaluate whether a particular rule should be incorporated into the model, and the algorithm runs either 1000 iterations or until convergence.

In all, 100 models were generated for each species, and the 10 best distribution models were selected using a best-practices procedure for identifying optimal models (Anderson et al. 2003) based on omission (leaving out true areas of occupation) and commission (including areas not potentially habitable) error statistics. Specifically, we used a soft omission threshold, focusing on the extreme $20 \%$ of the distribution of omission values across models. We then chose models presenting intermediate levels of commission (i.e., the central $50 \%$ of the commission index distribution). The 10 best models were summed in ArcView 3.2, and we took as a best and most conservative distribution estimate the areas in which a species was predicted to be present by all 10 of these best models. Finally, because species are often prevented from inhabiting the entire spatial extent of areas comprising their appropriate ecological niche by barriers to dispersal (Soberón and Peterson 2005), we reduced modeled distributions for the present to areas within or contiguous to known current distributions (Hellmayr 1924, Peters 1931, Hilty and Brown 1986, Sick 1993, Ridgely and Tudor 1994, Ridgely and Greenfield 2001, Hilty 2003). Given the small sample sizes available and prior experience with modeling such species in these regions (Peterson et al. 2002; MA and ATP, unpubl. data), we did not separate species data for independent model validation.

\section{STATISTICAL ANALYSES}

We evaluated expected effects of climate change on species distributions under a conservative assumption of no dispersal capabilities, which is likely appropriate for manakins, which tend to be habitat-restricted and sedentary. As such, we considered only the intersection of each species' predicted distribution after climate change with its present geographical distribution. This pro- cedure identifies the portions of current potential distributions that will remain habitable for the species after modeled climate change.

Centroids of present-day and predicted future distributions under the assumption of no dispersal were calculated using the centroid option in ArcInfo 8.0. Pairwise distances between these centroids for each species were computed as Euclidian distances, where:

$$
\mathrm{D}=\sqrt{ } \sum\left(\mathrm{v}_{i \mathrm{P}}-\mathrm{v}_{i \mathrm{~F}}\right)^{2},
$$

and $\mathrm{v}_{i \mathrm{P}}$ and $\mathrm{v}_{i \mathrm{~F}}$ are the values of the $i^{\text {th }}$ geographical coordinate (latitude or longitude) at the centroid of the species' present and future distributions, respectively.

The overall predicted future distribution of manakin diversity was represented by the sum of final predicted future distribution maps across all species. To summarize this diversity regionally, we divided the study region into six ecoregions generally recognized to comprise specific groups of Neotropical birds and usually considered in conservation plans (Central America-Chocó and NW South America, Andes, Amazon, Guiana Region, Cerrado, and Atlantic Forest; Fig. 1) and estimated numbers of species predicted to be lost from each ecoregion. Geographical limits of ecoregions were compiled based on the World Wildlife Fund's maps of terrestrial biorealms (<http://www.worldwildlife.org/wildworld/ profiles $/>$ ).

Effects of climate change on distributions were evaluated for montane and flatland species separately (species were classified as montane or flatland inhabitants based on the majority of their known ranges), and compared using nonparametric Mann-Whitney $U$-tests. We calculated levels of fragmentation for present and future distributions using the Patch and Proximity extensions in ArcView 3.2, estimating mean number of connected patches, patch sizes, distances to the nearest neighbor, and median isolation indices (according to index " $\mathrm{PX}_{92}$ "; Gustafson and Parker 1992) for each species. We used Wilcoxon matched-pairs tests to compare levels of fragmentation predicted for species distributions under present and future climates, and compared mean predicted changes in fragmentation level between present and future climates for flatland and montane species using Mann-Whitney $U$-tests. 


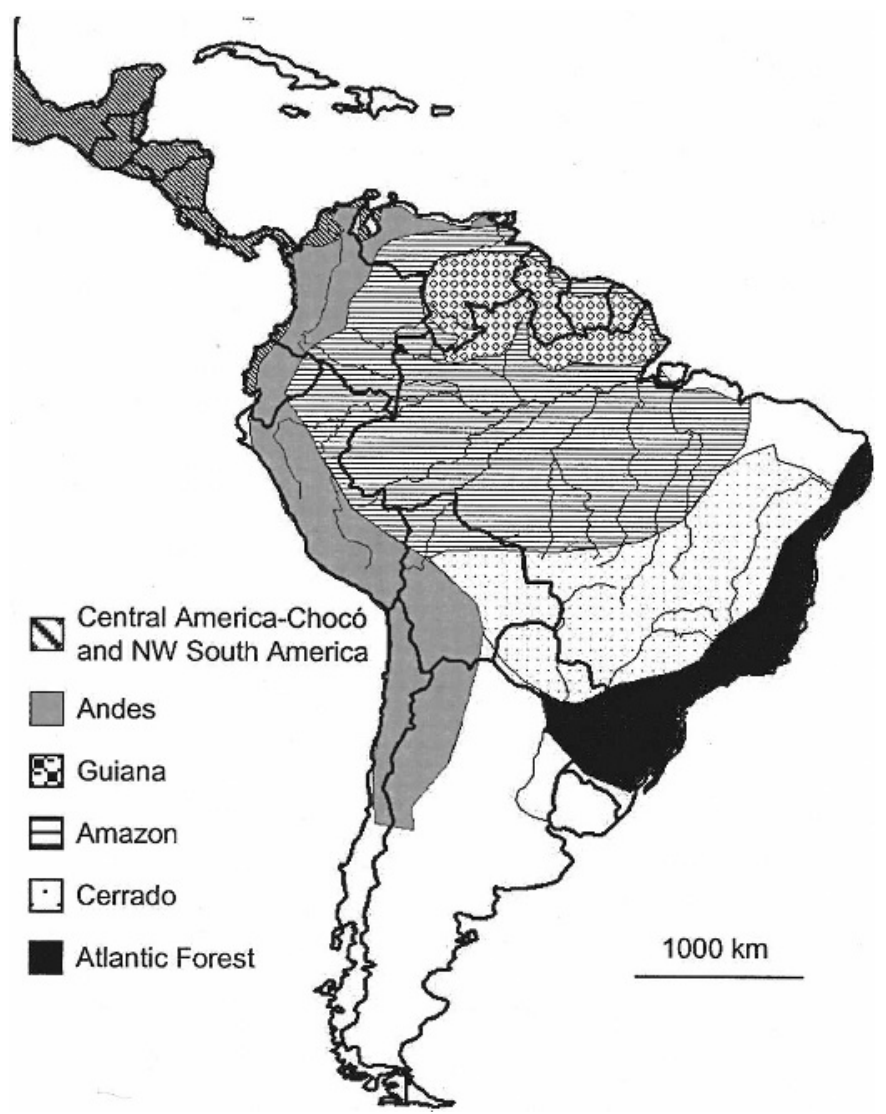

FIGURE 1. Geographical limits of ecoregions within the Neotropics used in this study.

\section{RESULTS}

In a previous study (MA and ATP, unpubl. data), coincidence of predictions of present-day geographic distributions with independent test data was highly significantly better than random models for all species (chi-square tests, all $\chi^{2}>6.8$, all $P<0.01$ ), suggesting good predictive power of models regarding the potential geographical distribution of each species. Based on this result, we were confident in continuing with further, extrapolative analyses.

Projections of niche models onto predicted future climate scenarios indicated moderate to extreme spatial changes in manakin distributions: under the assumption of no dispersal, areas of potential distributions were predicted to be reduced on average by $76 \%$ (range $=35 \%$ in the Blue-rumped Manakin [Lepidothrix isidorei] to $100 \%$ in the Yellow-crested Manakin
[Heterocercus flavivertex]) and dramatically reorganized, with range centroids shifting on average by $350 \mathrm{~km}$ in various directions (range $=6 \mathrm{~km}$ in the Pacific White-ruffed Manakin [Corapipo heteroleuca] to $1960 \mathrm{~km}$ in the Wingbarred Piprites [Piprites chloris]; Fig. 2). In general, about half the species were predicted to lose $>80 \%$ of their modeled present-day distributions, and 11 species were predicted to retain $<5 \%$ of their present suitable areas (Table 1). Consequent predicted changes in the distribution of manakin diversity include drastic reduction of species richness in forests in the Amazon Basin and a focusing of remaining species-rich areas along mountain ranges (Fig. 3).

Proportional reduction of habitable area was not correlated with modeled area of present-day distribution $\left(r^{2}=0.11, P>0.05\right)$. However, the ecological niche models predicted the effects of 

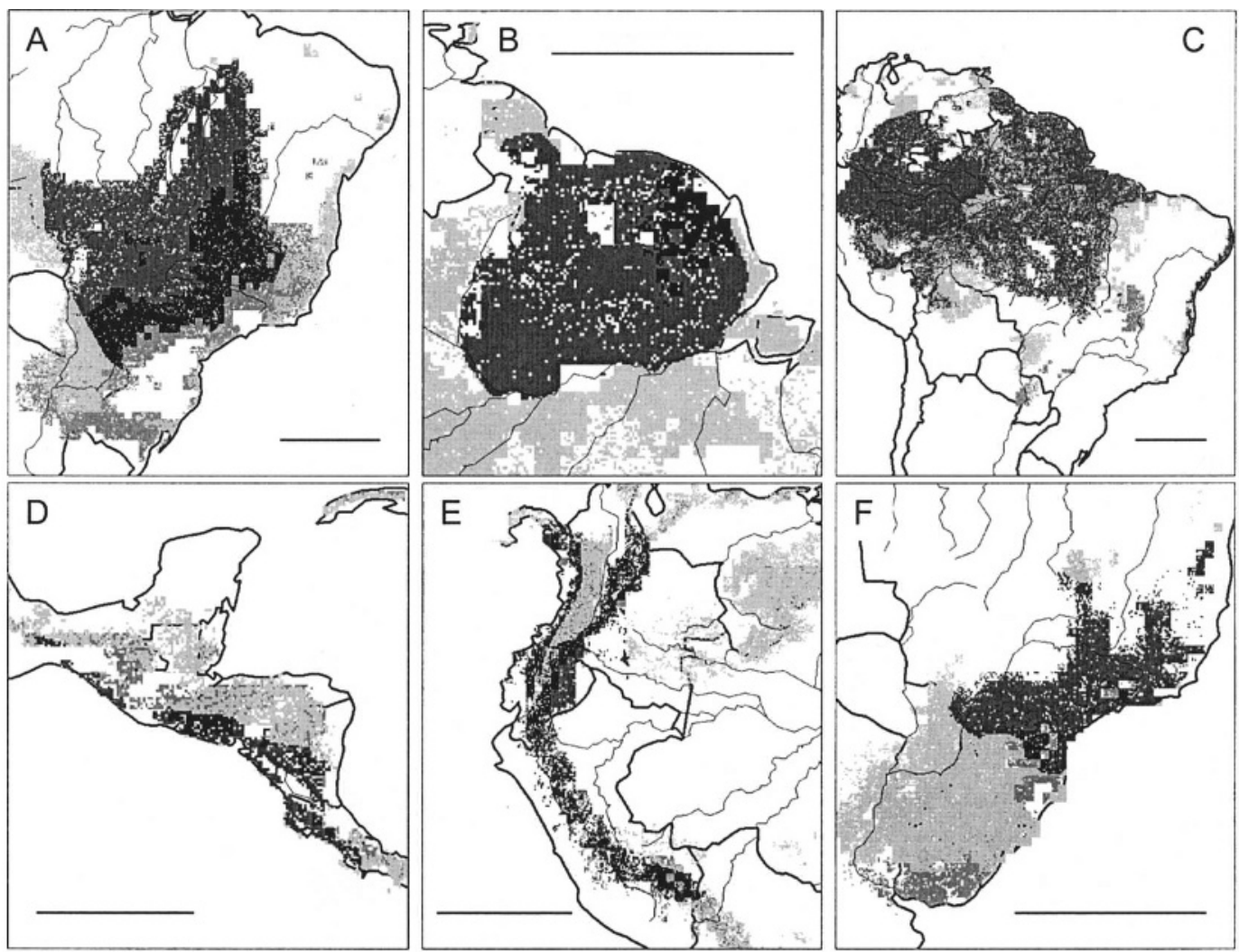

$=$ areas presently habitable that are projected to remain habitable within the known species range, = areas presently habitable but not predicted to remain habitable within the known species range, $\square=$ areas predicted to be habitable at present but not predicted to remain habitable outside the known species range, $\square=$ areas outside the known species range predicted to become habitable under the scenario of climate change.

FIGURE 2. Examples of future projections of climate change effects (four climate change scenarios averaged) on the geographical distributions of three species of manakins from flatlands: (A) Helmeted Manakin (Antilophia galeata) in the Cerrado, (B) White-fronted Manakin (Lepidothrix serena) in the Guiana Region, and (C) Blue-backed Manakin (Chiroxiphia pareola) in the Amazon and Atlantic Forest; and three from montane regions: (D) Long-tailed Manakin (Chiroxiphia linearis) in Central America, (E) Green Manakin (Chloropipo holochlora) in the Andes, and (F) Pin-tailed Manakin (Ilicura militaris) in the Atlantic Forest. Areas outside the known distributional range represent overly extensive predictions owing to historical factors and their occupancy would represent historical range restriction. Black bars represent $1000 \mathrm{~km}$.

climate change to be more severe for manakin species inhabiting flatlands than species in montane forests. Species inhabiting flatland forests in the Amazon and Cerrado ecoregions were predicted to lose $\sim 80 \%$ of habitable area; indeed, $\sim 20 \%$ of Cerrado manakin species would be potentially extinct from the biome under future climates (most of these species occur in other ecoregions). Predicted potential area loss and species extinction were lower in other ecoregions $(16 \%-50 \%$ and $0 \%-5 \%$, respectively), which are dominated by montane landforms. Furthermore, larger proportions of present-day distributional areas were predicted to remain habitable in montane situations than in flatlands (Mann-Whitney $U=110, P<0.01$; Fig. 4), and flatlands species were predicted to experience larger spatial shifts in their modeled potential distributions than montane species (Mann-Whitney $U=38.5, P<0.01$; Fig. 4). Several examples are shown in Fig. 2.

In general, suitable habitats were predicted to become more fragmented under future climates (Wilcoxon matched-pair test, all $Z>2.7$, all $P$ 
TABLE 1. Number of unique localities, areas of modeled present-day distribution, percent area loss and distance shifts of range centroids predicted under future climates, topography of inhabited area $(\mathrm{m}=$ montane, $\mathrm{f}=$ flatlands), and regions predicted to be habitable in the present day and to be lost through climate change for 49 species of Manakins and allies. Regions are: $\mathrm{AF}=$ Atlantic Forest, $\mathrm{CE}=$ Cerrado, $\mathrm{AM}=$ Amazon, $\mathrm{AD}=$ Andes, $\mathrm{GU}=$ Guiana Region, $\mathrm{CC}=$ Central America-Chocó and NW South America.

\begin{tabular}{|c|c|c|c|c|c|c|c|}
\hline \multirow[b]{2}{*}{ Species } & \multirow[b]{2}{*}{$\begin{array}{l}\text { Sample } \\
\text { localities }\end{array}$} & \multicolumn{2}{|l|}{ Area } & \multirow[b]{2}{*}{$\begin{array}{c}\text { Distance } \\
\text { shift }(\mathrm{km})\end{array}$} & \multicolumn{2}{|l|}{ Regions } & \multirow[b]{2}{*}{ Topography } \\
\hline & & $\begin{array}{c}\text { Present } \\
\left(\text { ha } \times 10^{-6}\right)\end{array}$ & $\begin{array}{l}\% \\
\text { loss }\end{array}$ & & Present & $\begin{array}{c}\text { Future } \\
\text { loss }\end{array}$ & \\
\hline $\begin{array}{l}\text { Helmeted Manakin (Antilophia } \\
\text { galeata) }\end{array}$ & 40 & 162.4 & 67 & 316.7 & $\mathrm{AF} ; \mathrm{CE} ; \mathrm{AM}$ & $\mathrm{AM}$ & $\mathrm{f}$ \\
\hline $\begin{array}{l}\text { Yungas Manakin (Chiroxiphia } \\
\text { boliviana) }\end{array}$ & 6 & 7.9 & 63 & 22.8 & $\mathrm{AD}$ & - & $\mathrm{m}$ \\
\hline $\begin{array}{l}\text { Blue Manakin (Chiroxiphia } \\
\text { caudata) }\end{array}$ & 186 & 98.0 & 93 & 218.1 & $\mathrm{AF} ; \mathrm{CE}$ & $\mathrm{CE}$ & $\mathrm{m}$ \\
\hline $\begin{array}{l}\text { Lance-tailed Manakin } \\
\text { (Chiroxiphia lanceolata) }\end{array}$ & 59 & 14.6 & 74 & 77.2 & $\mathrm{CC} ; \mathrm{AD}$ & - & $\mathrm{m}$ \\
\hline $\begin{array}{l}\text { Long-tailed Manakin } \\
\text { (Chiroxiphia linearis) }\end{array}$ & 26 & 8.5 & 62 & 48.3 & $\mathrm{CC}$ & - & $\mathrm{m}$ \\
\hline $\begin{array}{l}\text { Blue-backed Manakin } \\
\text { (Chiroxiphia pareola) }\end{array}$ & 79 & 344.2 & 100 & 1513.9 & $\begin{array}{l}\mathrm{AF} ; \mathrm{GU} ; \mathrm{AD} \\
\mathrm{AM} ; \mathrm{CE}\end{array}$ & $\mathrm{CE}$ & $\mathrm{f}$ \\
\hline $\begin{array}{l}\text { Green Manakin (Chloropipo } \\
\text { holochlora) }\end{array}$ & 48 & 40.2 & 50 & 177.5 & $\mathrm{CC} ; \mathrm{AD} ; \mathrm{AM}$ & - & $\mathrm{m}$ \\
\hline $\begin{array}{l}\text { Jet Manakin (Chloropipo } \\
\text { unicolor) }\end{array}$ & 6 & 16.3 & 65 & 112.2 & $\mathrm{AD} ; \mathrm{AM}$ & - & $\mathrm{m}$ \\
\hline $\begin{array}{l}\text { Olive Manakin (Chloropipo } \\
\text { uniformis) }\end{array}$ & 6 & 14.7 & 94 & 178.1 & GU & - & $\mathrm{m}$ \\
\hline $\begin{array}{l}\text { Caribbean White-ruffed } \\
\text { Manakin (Corapipo altera) }\end{array}$ & 44 & 9.4 & 49 & 32.2 & $\mathrm{CC} ; \mathrm{AD}$ & - & $\mathrm{m}$ \\
\hline $\begin{array}{l}\text { Pacific White-ruffed Manakin } \\
\text { (Corapipo heteroleuca) }\end{array}$ & 19 & 97.1 & 93 & 476.1 & $\mathrm{CC}$ & - & $\mathrm{m}$ \\
\hline $\begin{array}{l}\text { White-throated Manakin } \\
\text { (Corapipo gutturalis) }\end{array}$ & 36 & 2.2 & 46 & 6.1 & GU; AM & - & $\mathrm{f}$ \\
\hline $\begin{array}{l}\text { Colombian White-ruffed } \\
\text { Manakin (Corapipo } \\
\text { leucorrhoa) }\end{array}$ & 27 & 18.7 & 52 & 13.5 & $\mathrm{CC} ; \mathrm{AD} ; \mathrm{AM}$ & - & $\mathrm{m}$ \\
\hline $\begin{array}{l}\text { White-crowned Manakin } \\
\text { (Dixiphia pipra) }\end{array}$ & 118 & 401.3 & 92 & 774.1 & $\begin{array}{c}\mathrm{AF} ; \mathrm{GU} ; \mathrm{CC} ; \mathrm{AD} ; \\
\mathrm{AM}\end{array}$ & - & $\mathrm{f}$ \\
\hline $\begin{array}{l}\text { Yellow-crested Manakin } \\
\text { (Heterocercus flavivertex) }\end{array}$ & 13 & 26.0 & 100 & 441.3 & GU; AM & - & $\mathrm{f}$ \\
\hline $\begin{array}{l}\text { Flame-crested Manakin } \\
\text { (Heterocercus linteatus) }\end{array}$ & 15 & 137.7 & 98 & 623.8 & $\mathrm{CE} ; \mathrm{AM}$ & - & $\mathrm{f}$ \\
\hline $\begin{array}{l}\text { Pin-tailed Manakin (Ilicura } \\
\text { militaris) }\end{array}$ & 85 & 54.2 & 92 & 117.5 & $\mathrm{AF} ; \mathrm{CE}$ & - & $\mathrm{m}$ \\
\hline $\begin{array}{l}\text { Cerulean-capped Manakin } \\
\quad \text { (Lepidothrix caeruleocapilla) }\end{array}$ & 26 & 20.7 & 46 & 55.7 & $\mathrm{AD}$ & - & $\mathrm{m}$ \\
\hline $\begin{array}{l}\text { Blue-crowned Manakin } \\
\text { (Lepidothrix coronata) }\end{array}$ & 115 & 251.6 & 52 & 298.2 & GU; CC; AD; AM & - & $\mathrm{f}$ \\
\hline $\begin{array}{l}\text { Opal-crowned Manakin } \\
\text { (Lepidothrix iris) }\end{array}$ & 23 & 39.2 & 100 & 247.2 & $\mathrm{AM}$ & - & $\mathrm{f}$ \\
\hline $\begin{array}{l}\text { Blue-rumped Manakin } \\
\text { (Lepidothrix isidorei) }\end{array}$ & 11 & 14.5 & 35 & 133.1 & $\mathrm{AD}$ & - & $\mathrm{m}$ \\
\hline $\begin{array}{l}\text { Snow-capped Manakin } \\
\text { (Lepidothrix nattereri) }\end{array}$ & 21 & 70.0 & 73 & 239.3 & $\mathrm{AM}$ & - & $\mathrm{f}$ \\
\hline $\begin{array}{l}\text { White-fronted Manakin } \\
\text { (Lepidothrix serena) }\end{array}$ & 10 & 63.6 & 87 & 303.4 & GU; AM & - & $\mathrm{f}$ \\
\hline $\begin{array}{l}\text { Orange-bellied Manakin } \\
\text { (Lepidothrix suavissima) }\end{array}$ & 11 & 28.5 & 70 & 60.2 & GU; AM & - & $\mathrm{m}$ \\
\hline $\begin{array}{l}\text { Club-winged Manakin } \\
\quad \text { (Machaeropterus deliciosus) }\end{array}$ & 20 & 4.5 & 55 & 132.0 & $\mathrm{AD}$ & - & $\mathrm{m}$ \\
\hline
\end{tabular}


TABLE 1. Continued.

\begin{tabular}{|c|c|c|c|c|c|c|c|}
\hline \multirow[b]{2}{*}{ Species } & \multirow[b]{2}{*}{$\begin{array}{l}\text { Sample } \\
\text { localities }\end{array}$} & \multicolumn{2}{|l|}{ Area } & \multirow[b]{2}{*}{$\begin{array}{l}\text { Distance } \\
\text { shift }(\mathrm{km})\end{array}$} & \multicolumn{2}{|l|}{ Regions } & \multirow[b]{2}{*}{ Topography } \\
\hline & & $\begin{array}{c}\text { Present } \\
\left(\text { ha } \times 10^{-6}\right)\end{array}$ & $\begin{array}{c}\% \\
\text { loss }\end{array}$ & & Present & $\begin{array}{l}\text { Future } \\
\text { loss }\end{array}$ & \\
\hline $\begin{array}{l}\text { Fiery-capped Manakin } \\
\text { (Machaeropterus } \\
\text { pyrocephalus) }\end{array}$ & 39 & 118.4 & 97 & 1387.3 & $\mathrm{CE} ; \mathrm{AD} ; \mathrm{AM}$ & - & $\mathrm{f}$ \\
\hline $\begin{array}{l}\text { Eastern Striped Manakin } \\
\text { (Machaeropterus regulus) }\end{array}$ & 19 & 12.3 & 68 & 89.8 & $\mathrm{AF}$ & - & $\mathrm{f}$ \\
\hline $\begin{array}{l}\text { Western Striped Manakin } \\
\text { (Machaeropterus striolatus) }\end{array}$ & 38 & 169.2 & 74 & 374.1 & $\mathrm{AD} ; \mathrm{AM}$ & - & $\mathrm{m}$ \\
\hline $\begin{array}{l}\text { Orange-collared Manakin } \\
\text { (Manacus aurantiacus) }\end{array}$ & 17 & 3.9 & 83 & 148.4 & $\mathrm{CC}$ & - & $\mathrm{f}$ \\
\hline $\begin{array}{l}\text { White-collared Manakin } \\
\text { (Manacus candei) }\end{array}$ & 22 & 26.5 & 54 & 39.3 & $\mathrm{CC}$ & - & $\mathrm{f}$ \\
\hline $\begin{array}{l}\text { White-bearded Manakin } \\
\text { (Manacus manacus) }\end{array}$ & 171 & 601.6 & 83 & 629.6 & $\begin{array}{l}\text { AF; CE; AM; } \\
\text { GU; AD; CC }\end{array}$ & - & $\mathrm{f}$ \\
\hline $\begin{array}{l}\text { Milleri Bearded Manakin } \\
\text { (Manacus milleri) }\end{array}$ & 8 & 2.5 & 92 & 40.2 & $\mathrm{CC} ; \mathrm{AD}$ & - & $\mathrm{f}$ \\
\hline $\begin{array}{l}\text { Lemon-throated Manakin } \\
\text { (Manacus viridiventris) }\end{array}$ & 6 & 9.6 & 54 & 188.2 & $\mathrm{CC} ; \mathrm{AD}$ & - & $\mathrm{f}$ \\
\hline $\begin{array}{l}\text { Golden-collared Manakin } \\
\text { (Manacus vitellinus) }\end{array}$ & 17 & 10.9 & 77 & 79.3 & $\mathrm{CC} ; \mathrm{AD}$ & - & $\mathrm{f}$ \\
\hline $\begin{array}{l}\text { Golden-winged Manakin } \\
\text { (Masius chrysopteru) }\end{array}$ & 91 & 45.0 & 36 & 303.4 & $\mathrm{AD}$ & - & $\mathrm{m}$ \\
\hline $\begin{array}{l}\text { Crimson-hooded Manakin } \\
\text { (Pipra aureola) }\end{array}$ & 37 & 83.1 & 100 & 472.7 & GU; AM & - & $\mathrm{f}$ \\
\hline $\begin{array}{l}\text { Round-tailed Manakin (Pipra } \\
\text { chloromeros) }\end{array}$ & 47 & 34.8 & 52 & 51.6 & $\mathrm{CE} ; \mathrm{AD} ; \mathrm{AM}$ & - & $\mathrm{m}$ \\
\hline $\begin{array}{l}\text { Scarlet-horned Manakin (Pipra } \\
\text { cornuta) }\end{array}$ & 5 & 1.0 & 84 & 169.8 & $\mathrm{GU} ; \mathrm{AD} ; \mathrm{CC}$ & - & $\mathrm{m}$ \\
\hline $\begin{array}{l}\text { Golden-headed Manakin } \\
\text { (Pipra erytrocephala) }\end{array}$ & 152 & 392.5 & 74 & 340.9 & GU; CC; AD; AM & - & $\mathrm{f}$ \\
\hline $\begin{array}{l}\text { Band-tailed Manakin (Pipra } \\
\text { fascicauda) }\end{array}$ & 57 & 348.8 & 82 & 912.7 & $\mathrm{AF} ; \mathrm{CE} ; \mathrm{AD} ; \mathrm{AM}$ & - & $\mathrm{f}$ \\
\hline $\begin{array}{l}\text { Wire-tailed Manakin (Pipra } \\
\text { filiicauda) }\end{array}$ & 46 & 193.8 & 97 & 357.0 & GU; AD; AM & - & $\mathrm{f}$ \\
\hline $\begin{array}{l}\text { Red-capped Manakin (Pipra } \\
\text { mentalis) }\end{array}$ & 49 & 36.1 & 49 & 112.9 & $\mathrm{CC} ; \mathrm{AD}$ & - & $\mathrm{f}$ \\
\hline $\begin{array}{l}\text { Red-headed Manakin (Pipra } \\
\text { rubrocapilla) }\end{array}$ & 69 & 248.0 & 95 & 465.3 & $\mathrm{AF} ; \mathrm{AM}$ & - & $\mathrm{f}$ \\
\hline $\begin{array}{l}\text { Black Manakin (Xenopipo } \\
\text { atronitens) }\end{array}$ & 28 & 291.5 & 98 & 1063.0 & GU; AM & - & $\mathrm{f}$ \\
\hline $\begin{array}{l}\text { Wied's Tyrant-Manakin } \\
\text { (Neopelma aurifrons) }\end{array}$ & 8 & 53.3 & 73 & 206.7 & $\mathrm{AF}$ & - & $\mathrm{m}$ \\
\hline $\begin{array}{l}\text { Pale-bellied Tyrant-Manakin } \\
\text { (Neopelma pallescens) }\end{array}$ & 15 & 178.0 & 91 & 601.5 & $\mathrm{AF} ; \mathrm{CE} ; \mathrm{AM} ; \mathrm{GU}$ & $\begin{array}{l}\mathrm{AM} ; \\
\mathrm{GU}\end{array}$ & $\mathrm{f}$ \\
\hline $\begin{array}{l}\text { Cinnamon Tyrant-Manakin } \\
\text { (Neopipo cinnamomea) }\end{array}$ & 12 & 223.8 & 96 & 517.5 & $\mathrm{AD} ; \mathrm{GU} ; \mathrm{AM}$ & - & $\mathrm{f}$ \\
\hline $\begin{array}{l}\text { Wing-barred Piprites (Piprites } \\
\text { chloris) }\end{array}$ & 17 & 341.8 & 93 & 1964.6 & $\begin{array}{c}\mathrm{AF} ; \mathrm{GU} ; \mathrm{AM} \\
\mathrm{AD} ; \mathrm{CC}\end{array}$ & $\mathrm{CC}$ & $\mathrm{f}$ \\
\hline $\begin{array}{l}\text { Dwarf Tyrant-Manakin } \\
\text { (Tyranneutes stoltzmanni) }\end{array}$ & 17 & 207.7 & 99 & 223.1 & $\mathrm{GU} ; \mathrm{AD} ; \mathrm{AM}$; $\mathrm{CE}$ & $\mathrm{CE}$ & $\mathrm{f}$ \\
\hline
\end{tabular}

$<0.01$; Table 2), although flatland species were predicted to become confined to more highly reduced fragments in relation to present distributions than montane species (Mann-Whitney $U$-test, patch area: $U=156, P<0.01$; all other $U>176$, all other $P>0.23$ ). In addition, predicted isolation indices showed that suitable habitat patches will be more isolated in the future only for flatland species (Wilcoxon matched-pair tests, flatland species: $Z=2.4$, $P<0.05$; montane species: $Z=0.3, P>0.05$; Table 2). 


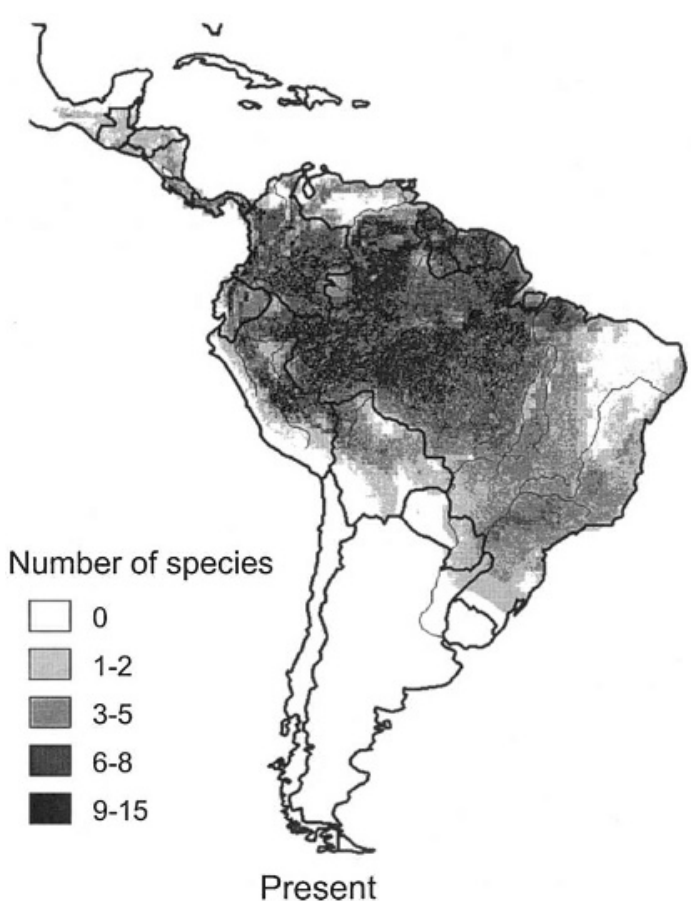

FIGURE 3. Species diversity of manakins across distributions for present and predicted future climates.

\section{DISCUSSION}

This study predicted considerable effects of future climate changes on the distribution and diversity of manakins throughout the Neotropics. Our approach focused on ecological niche modeling based solely on the responses of species to climatic and topographic variables, and did not evaluate effects of climate changes on forested habitats. Considering that climatic variables may often be surrogates for occurrence of plant species and vegetation types (Siqueira and Peterson 2003), and may not affect the persistence of bird species directly, other effects of future climates may affect distributions of manakins beyond those foreseen here. More dramatic effects would be expected if vegetation cover changes abruptly, or if potential effects on habitat parameters such as plant phenology and fruit availability are considered; conversely, effects might be less pronounced if habitat structure changes moderately in response to new climatic conditions. Nevertheless, we expect relatively minor variations from the species loss and distributional changes predicted here, as ecological niches

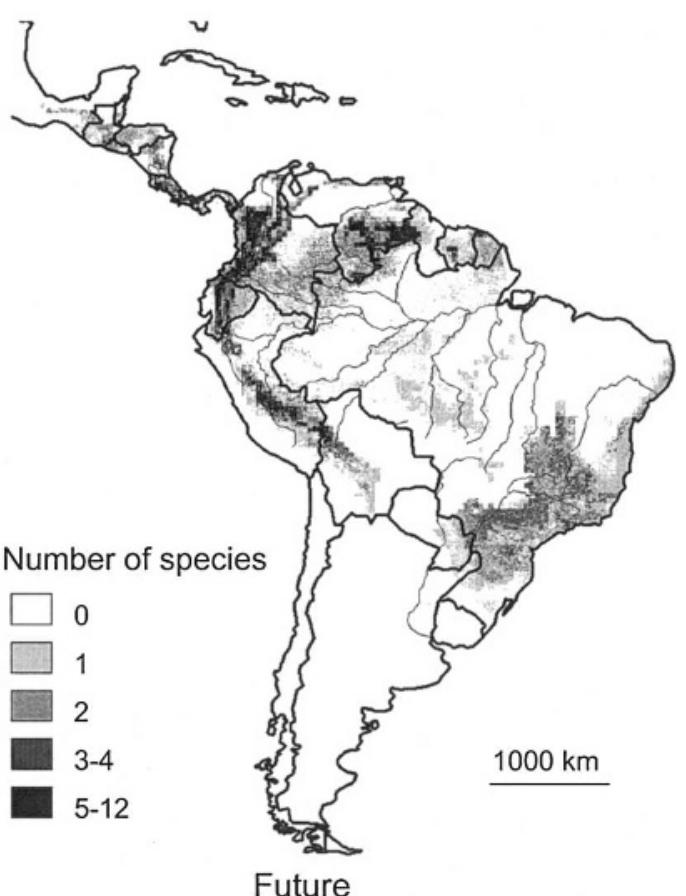

the Neotropics according to modeled geographic have defined species distributions accurately on both ecological and evolutionary timescales (Huntley et al. 1989, Peterson et. al. 1999, Martinez-Meyer et al. 2004).

The Amazon and Cerrado regions are predicted to lose a large portion of their suitable manakin habitats, therefore a major reduction in diversity of these birds in flatland forests is expected. While manakin diversity is predicted to decrease dramatically in the Amazon region, overall species composition is not expected to be reduced greatly. In contrast, forested habitats in the Cerrado are predicted to face considerable loss of both habitable area and species. Although most manakins occurring in the Cerrado are not restricted to that region, generally inhabiting transitional zones to other biomes, Cerrado bird species diversity may be severely threatened, as previous assessments have shown drastic effects of future climates for Cerrado tree species (Siqueira and Peterson 2003). Predictions of vegetation cover and structure for these areas are, however, difficult to postulate. Although paleoclimatic reconstructions for the Amazon Basin indicated that 


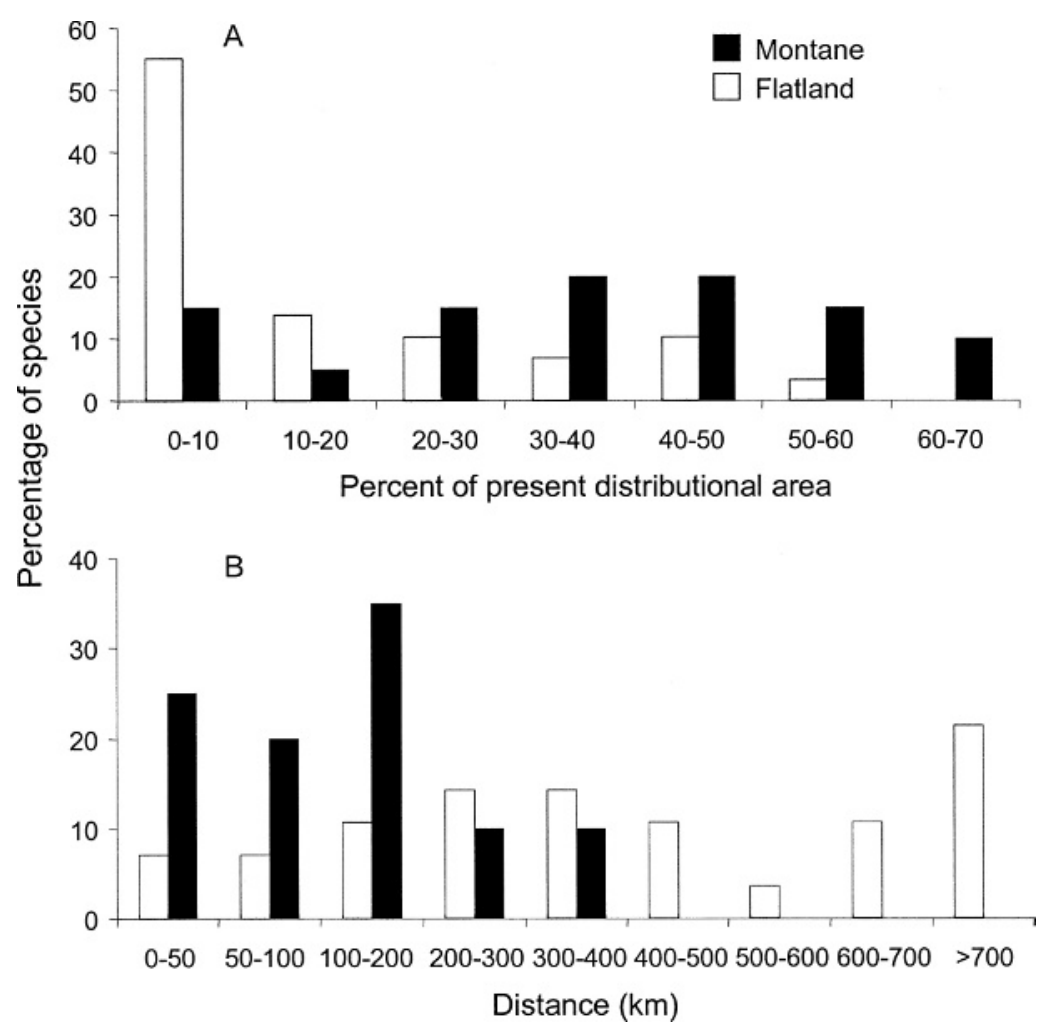

FIGURE 4. Percentage of manakin species in each category of projected change in (A) potential distributional areas (expressed as percent of present distributional area), and (B) projected distance that range centroids would shift, as a result of modeled climate change processes in montane and flatland habitats.

savanna formations did not expand in warmer interglacial periods during the Holocene (Hoorn 1997, Harbele and Maslin 1999, Colinvaux et al. 2000, Pennington et al. 2000, Bonnacorso et al. 2006), some studies have shown that dry, sandy soil forests may have benefited from these climates (Prado and Gibbs
1993, Pennington et al. 2000, 2004) and may become more available in the future. In fact, the composition of biotas in the past indicates that climate changes affect individual species differently, and future biotas may not have contemporary analogues (Graham 1988, Hunter et al. 1988). Furthermore, the increase of $3.0-5.1^{\circ} \mathrm{C}$

TABLE 2. Spatial statistics for modeled species distributions under present and future climates, for flatland and montane species. Comparisons are based on mean patch area and distance to the nearest neighbor (NN) and on a median isolation index ( $\mathrm{PX}_{92}$; Gustafson and Parker 1992). Future estimates differing significantly from present values are marked with ${ }^{*}$ denoting $P<0.05$ and ${ }^{*} *$ denoting $P<0.01$ (Wilcoxon matched pairs test).

\begin{tabular}{clccccc}
\hline \hline $\begin{array}{c}\text { Time } \\
\text { period }\end{array}$ & Topography & $\begin{array}{c}\text { Number of } \\
\text { species } \pm \mathrm{SE}\end{array}$ & $\begin{array}{c}\text { Number of } \\
\text { patches } \pm \mathrm{SE}\end{array}$ & $\begin{array}{c}\text { Patch area } \pm \mathrm{SE} \\
\left(\mathrm{km} \times 10^{-3}\right)\end{array}$ & $\begin{array}{c}\mathrm{NN} \pm \mathrm{SE} \\
\left(\mathrm{km} \times 10^{2}\right)\end{array}$ & $\mathrm{PX}_{92} \times 10^{2} \pm \mathrm{SE}$ \\
\hline Present & All species & 49 & $226.2 \pm 37.1$ & $11.0 \pm 3.9$ & $3.5 \pm 0.4$ & $0.1 \pm 0.1$ \\
& Flatland & 29 & $318.3 \pm 55.0$ & $13.3 \pm 6.2$ & $3.4 \pm 0.4$ & $0.0 \pm 0.0$ \\
& Montane & 20 & $92.6 \pm 21.8$ & $7.7 \pm 3.5$ & $3.8 \pm 0.8$ & $0.3 \pm 0.3$ \\
Future & All species & 49 & $136.1 \pm 32.6$ & $1.5 \pm 0.3 * *$ & $19.5 \pm 8.9^{* *}$ & $29.5 \pm 21.7^{*}$ \\
& Flatland & 29 & $173.1 \pm 52.9$ & $1.3 \pm 0.4^{* *}$ & $27.7 \pm 14.8^{* *}$ & $41.0 \pm 36.0^{*}$ \\
& Montane & 20 & $82.5 \pm 18.4$ & $2.0 \pm 0.6^{* *}$ & $7.6 \pm 1.7^{* *}$ & $12.8 \pm 10.8$ \\
\hline
\end{tabular}


in temperature predicted for future decades largely exceeds records for oscillations of warm climates in the past (e.g., $1.7^{\circ} \mathrm{C}$ during the Eemian epoch, 130000 bp; Sirocko et al. 2005).

In general, forested areas predicted to hold suitable habitats under future climates are of conservation importance for flatland faunas. However, predicted species losses should perhaps be regarded with some caution, as reactions to unknown climate combinations that species would likely experience under future climate regimes, to some degree at least, are unknown (Graham 1988, Hunter et al. 1988). Montane regions, on the other hand, appear to be crucial for conservation of Neotropical manakin species diversity. Montane forests are predicted to hold the highest local manakin diversity in coming decades and, although models predicted less severe effects of climate change in montane forests, montane species are nonetheless predicted to see significant reductions in distribution $(>30 \%)$, and would likely also experience new climatic conditions under future climate regimens, with unknown effects on their persistence. Furthermore, the accelerated deforestation rates that some of these habitats are facing (da Fonseca et al. 2000, Myers et al. 2000) suggest that montane forests predicted to remain habitable in the future on climatic grounds should be assigned top priority for conservation action, as they may prove highly endangered on land-use considerations.

Flatland and montane topographies present different scenarios for changing distributions under future climates. The reduced horizontal shifts in suitable conditions in montane versus flatlands regions are instead associated with changes in distributional area along altitudinal gradients (Peterson 2003). This pattern probably results from the greater environmental heterogeneity found within grid squares in the more topographically diverse montane regions. Species inhabiting montane forests may also be more flexible regarding habitat requirements, as some species undergo altitudinal migrations among seasons (Rosselli 1994, Blake and Loiselle 2002; MA, unpubl. data). Altitudinal shifts may nevertheless make these species more vulnerable, as they may require lowland habitats for continuous fruit availability (Rosselli 1994). More accurate results will be possible once models of climate change become available at finer spatial scales, but the broad responses of flatland and montane species to climate changes will likely be similar to the current results, given the variation in topography and spatial heterogeneity between these habitats.

Our assumption of no dispersal is unlikely to have influenced our results regarding effects of climate changes and topography on distributions of species. In the original publication outlining these effects (Peterson 2003), similar patterns were observed among North American birds when very liberal dispersal scenarios were considered, and dispersal ability affected only the distances by which geographic distributions shifted.

Although local manakin populations are usually not particularly sensitive to habitat fragmentation (Andrade 1999, Anciães and Marini 2000, Rosselli et al. 2002), effects of climate changes at regional scales (e.g., area loss and isolation, distributional shifts, metapopulation dynamics) may overcome local population processes. Under this scenario of accentuated isolation and reduction of habitable area, manakin species may indeed become threatened. Reduced patch size suggests increasing dependence of local populations on suitable habitats at regional scales to preserve metapopulation dynamics.

Niche modeling provides a useful means of exploring the effects of future climate change on biodiversity patterns. As such, it may prove helpful in identifying priority areas for conservation, i.e., areas where future climates will likely promote gain versus loss of biodiversity. Given the large predicted distributional shifts for flatlands species, their present-day ranges offer little information about future distributions. Thus, effective conservation of flatland species, in particular, depends on accurate predictive methods, as indicated here and in previous studies (Peterson et al. 2001, 2002, Peterson 2003). Conservation of montane species, on the other hand, requires techniques that are able to accurately locate remnant habitats that will likely remain habitable after climate change.

\section{ACKNOWLEDGMENTS}

We would like to thank museum personnel, especially J. Dean, S. Hackett, L. Joseph, J. Nacinovic, M. Raposo, J. Van Remsen, N. Rice, M. Rodrigues, L. Silveira, and P. Sweet for access to collections of the National Museum of Natural History, Field Museum 
of Natural History, Academy of Natural Science of Philadelphia, Museu Nacional da Universidade Federal do Rio de Janeiro, Louisiana State University Museum of Natural Science, Departamento de Zoologia da Universidade Federal de Minas Gerais, Museu de Zoologia Natural da Universidade Federal de São Paulo, and American Museum of Natural History. A. Aleixo, R. Anderson, G. Garratt, J. Gonçalves, I. de Sá, V. Tavares, M. Valle, G. Vieira, and M. Weksler hosted MA during several stages of this research. R. Anderson, E. Bonaccorso, E. Martínez-Meyer, Y. Nakazawa, M. Ortega-Huerta, and M. Papes kindly helped with the modeling and data analysis, and provided useful input through discussions. We are most thankful to Robert Holt and an anonymous reviewer for their suggestions for improving the manuscript. MA received a doctoral scholarship from Coordenação de Aperfeiçoamento de Pessoal de Nível Superior (CAPES), Collection Study Grants from the American Museum of Natural History, and several Panorama grants from the Natural History Museum and Biodiversity Research Center at the University of Kansas.

\section{LITERATURE CITED}

ANCIÃEs, M., AND M. Â. MARINI. 2000. The effects of fragmentation on fluctuating asymmetry in passerine birds of Brazilian tropical forests. Journal of Applied Ecology 37:1013-1028.

Anderson, R. P., D. LeW, AND A. T. Peterson. 2003. Evaluating predictive models of species' distributions: criteria for selecting optimal models. Ecological Modelling 162:211-232.

Andrade, R. D. 1999. Deslocamento e uso de capoes de mata por aves do Parque Nacional da Serra da Canastra, Minas Gerais. M.Sc. thesis, Universidade Federal de Minas Gerais, Belo Horizonte, Brazil.

Austin, M. P., A. O. Nicholls, And C. R. MARGULES. 1990. Measurement of the realized qualitative niche: environmental niches of five Eucalyptus species. Ecological Monographs 60:161-177.

Blake, J. G., AND B. A. Loiselle. 2002. Habitat use, movements, and survival of manakins (Pipridae) in second-growth and old-growth forests. Auk 119:132-148.

Bonnacorso, E., I. Koch, and A. T. Peterson. 2006. Pleistocene fragmentation of Amazon species' ranges. Diversity and Distributions 12:157-164.

Brown, J. H., AND M. V. Lomolino. 1998. Biogeography. 2nd ed. Sinauer Associates, Sunderland, MA.

Brown, J. H., T. J. Valone, And C. G. Curtin. 1997. Reorganization of an arid ecosystem in response to recent climate change. Proceedings of the National Academy of Sciences USA 94:9729-9733.

Carpenter, G., A. N. Gillison, And J. Winter. 1993. DOMAIN: a flexible modeling procedure for mapping potential distributions of animals and plants. Biodiversity and Conservation 2: $667-680$
Chapin, F. S., III, E. S. Zavaleta, V. T. Eviner, R. L. Naylor, P. M. Vitousek, H. L. Reynolds, D. U. Hooper, S. Lavorel, O. E. Sala, S. E. Hobbie, M. C. Mack, And S. DiAz. 2000. Consequences of changing biodiversity. Nature 405:234-242.

Colinvaux, P. A., P. E. De Oliveira, And M. B. BUSH. 2000. Amazonian and Neotropical plant communities on glacial time-scales: the failure of the aridity and refuge hypotheses. Quaternary Science Reviews 19:141-169.

DA Fonseca, G. A. B., A. Balmford, C. Bibby, L. Boitani, F. Corsi, T. BroOKS, C. Gascon, S. Olivieri, R. Mittermeier, N. Burgess, E. Dinerstein, D. Olson, L. Hannah, J. LOVETt, D. Moyer, C. Rahbek, S. Stuart, And P. Williams. 2000. Following Africa's lead in setting priorities. Nature 405:393-394.

Dobson, A., A. Jolly, And D. Rubenstein. 1989. The greenhouse effect and biological diversity. Trends in Ecology \& Evolution 4:64-68.

Flato, G. M., G. L. Boer, W. G. Lee, N. A. McFarlane, D. Ramsden, M. C. Reader, AND A. J. Weaver. 1999. The Canadian Centre for Climate Modelling and Analysis global coupled model and its climate. Climate Dynamics 16:451-467.

GRAHAM, R. W. 1988. The role of climatic change in the design of biological reserves: the paleoecological perspective for conservation biology. Conservation Biology 2:391-394.

GRINNELL, J. 1917. Field tests of theories concerning distributional control. American Naturalist 51:115-128.

GRINNELL, J. 1924. Geography and evolution. Ecology 5:225-229.

Gustafson, E. J., AND G. R. PARKer. 1992. Relationship between landcover proportion and indices of landscape spatial pattern. Landscape Ecology 7:101-110.

Haberle, S. G., AND M. A. Maslin. 1999. Late Quaternary vegetation and climate change in the Amazon basin based on a 50,000 year pollen record from the Amazon Fan, ODP Site 932. Quaternary Research 51:27-38.

Hellmayr, C. E. 1924. Catalogue of birds of the Americas. Field Museum of Natural History Publications, Zoological Series no. 6.

Hilty, S. L. 2003. Birds of Venezuela. Princeton University Press, Princeton, NJ.

Hilty, S. L., AND W. L. Brown. 1986. A guide to the birds of Colombia. Princeton University Press, Princeton, NJ.

Holt, R. D. 1990. The microevolutionary consequences of climate change. Trends in Ecology \& Evolution 5:311-315.

Holt, R. D. 1996. Adaptive evolution in source-sink environments: direct and indirect effects of density-dependence on niche evolution. Oikos 75:182-192.

Holt, R. D., AND M. S. GAINES. 1992. Analysis of adaptation in heterogeneous landscapes: implications for the evolution of fundamental niches. Evolutionary Ecology 6:433-447. 
Holt, R. D., AND R. Gomulkiewicz. 1996. The evolution of species' niches: a population dynamic perspective, p. 25-50. In H. G. Othmer, F. R. Adler, M. A. Lewis, and J. C. Dallon [EDS.], Case studies in mathematical modeling: ecology, physiology and cell biology. Prentice-Hall, Saddle River, NJ.

Hoorn, C. 1997. Palynology of the Pleistocene glacial/interglacial cycles of the Amazon Fan (holes 940A, 944A, and 946A). Proceedings of the Ocean Drilling Program Scientific Results 155:397-409.

Houghton, J. T., Y. Ding, D. J. GRiggs, M. NoGuer, P. J. VAN DER LINDEN, X. DAI, K. MASKell, and C. A. JoHnSON [EDS.]. 2001. Climate change 2001: the scientific basis. Contribution of Working Group I to the third assessment report of the IPCC. Cambridge University Press, New York.

Hunter, M. L., JR, G. L. JaCobson JR, AND T. WEBB. 1988. Paleoecology and the coarse-filter approach to maintaining biological diversity. Conservation Biology 2:375-385.

Huntley, B., P. J. Bartlein, And I. C. Prentice. 1989. Climatic control of the distribution and abundance of beech (Fagus L.) in Europe and North America. Journal of Biogeography 16:551-560.

Johnston, K. M., AND O. J. SchMitz. 1997. Wildlife and climate change: assessing the sensitivity of selected species to simulated doubling of atmospheric $\mathrm{CO}_{2}$. Global Change Biology 3:531-544.

KADMON, R., AND J. Heller. 1998. Modelling faunal responses to climatic gradients with GIS: land snails as a case study. Journal of Biogeography 25:527-539.

KARl, T. R., R. W. Knight, D. R. EAsterling, AND R. G. QUAYLE. 1996. Indices of climate change for the United States. Bulletin of the American Meteorological Society 77:279-292.

Kawecki, T. J., And S. C. Stearns. 1993. The evolution of life histories in spatially heterogeneous environments: optimal reaction norms revisited. Evolutionary Ecology 7:155-174.

MacArthur, R. 1972. Geographical ecology. Princeton University Press, Princeton, NJ.

Magnuson, J. 2001. 150-year global ice record reveals major warming trend. Inter-American Institute for Global Change Research 24:22-25.

Martínez-Meyer, E., A. T. Peterson, And W. W. HARGRove. 2004. Ecological niches as stable distributional constraints on mammal species, with implications for Pleistocene extinctions and climate change projections for biodiversity. Global Ecology and Biogeography 13:305-314.

Myers, N., R. A. Mittermeier, C. G. MittermeiER, G. A. B. DA FonsecA, AND J. Kent. 2000. Biodiversity hotspots for conservation priorities. Nature 403:853-858.

NAKicenovic, N., and R. Swart [EDS.]. 2000. Emission scenarios: a special report of Working Group III of the Intergovernmental Panel on Climate Change. Cambridge University Press, Cambridge, UK.
Nix, H. A. 1986. A biogeographic analysis of Australian elapid snakes, p. 4-15. In R. Longmore [ED.], Atlas of elapid snakes of Australia. Australian Government Publishing Service, Canberra.

Parmesan, C., N. Ryrholm, C. Stefanescu, J. K. Hill, C. D. Thomas, H. Descimon, B. Huntley, L. Kaila, J. Kullberg, T. Tammaru, J. Tennent, J. A. Thomas, And M. WARren. 1999. Poleward shift of butterfly species' ranges associated with regional warming. Nature 399:579-583.

Pennington, R. T., M. Lavin, D. E. Prado, C. A. Pendry, S. K. Pell, And C. A. Butterworth. 2004. Historical climate change and speciation: Neotropical seasonally dry forest plants show patterns of both Tertiary and Quaternary diversification. Philosophical Transactions of the Royal Society of London Series B 359:359-537.

Pennington, R. T., D. E. Prado, A. Coling, And C. A. PENDRY. 2000. Neotropical seasonally dry forest and Quaternary vegetation changes. Journal of Biogeography 27:261-273.

Perry, D. A., J. G. Borchers, S. L. Borchers, AND M. P. AMARANTHUS. 1990. Species migrations and ecosystem stability during climate change: the belowground connection. Conservation Biology 4:266-274.

Peters, J. L. 1931. Checklist of birds of the world. Vol. 8. Harvard University Press, London.

Peters, R. L., And J. D. S. Darling. 1985. The greenhouse effect and nature reserves. Bioscience 35:707-717.

Peters, R. L., AND J. P. Myers. 1991-1992. Preserving biodiversity in a changing climate. Issues in Science and Technology 19911992:66-72.

Peterson, A. T. 2003. Projected climate change effects on Rocky Mountain and Great Plain birds: generalities of biodiversity consequences. Global Change Biology 9:647-655.

Peterson, A. T., E. Martínez-Meyer, C. GonZALES-SAlAZAR, AND P. W. HALl. 2004. Modeled climate change effects on distributions of Canadian butterfly species. Canadian Journal of Zoology 82:851-858.

Peterson, A. T., M. A. Ortega-Huerta, J. BArtley, V. SÁNCHEZ-Cordero, J. SObERón, R. H. Buddemeier, AND D. R. B. STOCKWELl. 2002. Future projections for Mexican faunas under global climate change. Nature 416:626 629.

Peterson, A. T., V. SAnchez-Cordero, J. SoBERÓN, J. BARTLEY, R. W. BUDDEMEIER, AND A. G. NAVARro-SigüEnZA. 2001. Effects of global climate change on geographic distributions of Mexican Cracidae. Ecological Modelling 144:21-30.

Peterson, A. T., J. Soberón, And V. SanchezCordero. 1999. Conservatism of ecological niches in evolutionary time. Science $285: 1265$ 1267.

Pope, V. D., M. L. Gallani, V. J. Rowntree, And R. A. Stratton. 2000. The impact of new physical parametrizations in the Hadley Centre 
climate model: HadAM3. Climate Dynamics 16:123-146.

Pounds, J. A., M. L. P. Fogden, AND J. H. CAMPBELl. 1999. Biological response to climate change on a tropical mountain. Nature 398:611615.

Prado, D. E., AND P. E. GibBs. 1993. Patterns of species distributions in the dry seasonal forest of South America. Annals of the Missouri Botanical Garden 80:902-927.

PrICE, J. 2000. Modeling the potential impacts of climate change on the summer distributions of Massachussetts passerines. Bird Observer 28: 224-230.

Rice, N. H., E. Martínez-Meyer, And A. T. PETERSON. 2003. Ecological niche differentiation in the Aphelocoma jays: a phylogenetic perspective. Biological Journal of the Linnaean Society 80:369-383.

Ridgely, R. S., AND P. GReEnfield. 2001. The birds of Ecuador. Vol. 1-2. Cornell University Press, Ithaca, NY.

Ridgely, R. S., AND G. Tudor. 1994. The birds of South America. Vol. 2. University of Texas Press, Austin, TX.

Root, T. L., J. T. Price, K. R. Hall, S. H. Schneider, C. Rosenzweig, And J. A. PoundS. 2003. Fingerprints of global warming on wild animals and plants. Nature 421:57-60.

Rosselli, L. 1994. The annual cycle of the Whiteruffed Manakin Corapipo leucorrhoa, a tropical frugivorous altitudinal migrant, and its food plants. Bird Conservation International 4:143160.

Rosselli, L., P. Vasquez, And I. Ayub. 2002. The courtship displays and social system of the White-ruffed Manakin in Costa Rica. Wilson Bulletin 114:165-178.

Roura-Pascual, N., A. Suarez, C. Gómez, P. Pons, Y. Touyama, A. L. Wild, AND A. T. PETERSON. 2005. Geographic potential of Argentine ants (Linepithema humile Mayr) in the face of global climate change. Proceedings of the Royal Society of London Series B 271:25272535.

Sick, H. 1993. Birds in Brazil: a natural history. Princeton University Press, Princeton, NJ.
Siqueira, M. F., And A. T. Peterson [Online]. 2003. Consequences of global climate change for geographic distributions of Cerrado tree species. Biota Neotropica v3 (n2). <http://www. biotaneotropica.org.br/v3n2> (17 April 2006).

Sirocko, F., K. Seelos, K. Schaber, B. Rein, F. Dreher, M. Diehl, R. LeHne, K. JÄGER, M. KrbetscheK, AND D. DEgERING. 2005. A late Eemian aridity pulse in central Europe during the last glacial inception. Nature 436:833-836.

Soberón, J., AND A. T. Peterson. 2005. Interpretation of models of fundamental ecological niches and species' distributional areas. Biodiversity Informatics 2:1-10.

STOCKWELL, D. R. B. 1999. Genetic algorithms II, p. 123-144. In A. H. Fielding [ED.], Machine learning methods for ecological applications. Kluwer Academic Publishers, Boston, MA.

Stockwell, D. R. B., AND I. R. Noble. 1992. Induction of sets of rules from animal distribution data: a robust and informative method of analysis. Mathematics and Computers in Simulation 33:385-390.

Stockwell, D. R. B., And D. P. Peters. 1999. The GARP modelling system: problems and solutions to automated spatial prediction. International Journal of Geographic Information Systems 13:143-158.

Thomas, C. D., A. Cameron, R. E. Green, M. BakKenes, L. J. BeAumont, Y. C. CollingHAM, B. F. N. ERAsmus, M. FERreira DE Siqueira, A. Grainger, L. Hannah, L. Hughes, B. Huntley, A. S. VAN JAARSVEld, G. F. Midgley, L. Miles, M. A. OrtegAHuerta, A. Townsend Peterson, O. L. Phillips, AND S. E. Williams. 2004. Extinction risk from climate change. Nature 427:145148.

Walther, G. R., E. Post, P. Convey, A. Menzel, C. Parmesan, T. J. C. Beebee, J. M. FromenTIN, O. HoEgh-GuldberG, AND F. BAirlein. 2002. Ecological responses to recent climate change. Nature 416:389-395.

XU, D., AND H. YAN. 2001. A study of the impacts of climate change on the geographic distribution of Pinus koraiensis in China. Environmental International 27:201-205. 